\title{
POLSKA TERMINOLOGIA JEZYKOZNAWCZA W WĘGIERSKIEJ TRADYCJI POLONISTYCZNEJ
}

\begin{abstract}
Słowa kluczowe: terminologia, termin językoznawczy, język polski, język węgierski, opis struktury języka, nauczanie/uczenie się języka polskiego

Streszczenie: Polszczyzna i język węgierski są językami odrębnymi zarówno pod względem genetycznym, jak i typologicznym. Język polski jest językiem indoeuropejskim, słowiańskim, fleksyjnym, natomiast węgierszczyzna jest językiem uralskim, ugrofińskim, aglutynacyjnym. W związku z tymi odrębnościami część kategorii gramatycznych w pełni się nie pokrywa. Dotyczy to zwłaszcza nieistniejącego w węgierszczyźnie rodzaju gramatycznego, liczebnika zbiorowego, przyimka, aspektu czasownika, a także w odmienny sposób wyrażanego przypadka. W węgierskim językoznawstwie polonistycznym istnieją usankcjonowane tradycją terminy nazywające wskazane kategorie. Niniejszy artykuł jest poświęcony ich analizie.
\end{abstract}

\section{WPROWADZENIE}

Węgierskie językoznawstwo polonistyczne ma bogatą tradycję, jej owocem są liczne opracowania lingwistyczne, w tym glottodydaktyczne (por. np. Kerényi, Szabó, Varsány 1966, Bańczerowski 1976, 1995, 2001a, 2001b, 2007; Bańczerowski, Szabó, Bakanyi 1980; Mroczko, 1967; Stefańczyk 1996; Pátrovics 2000, 2004, 2011), leksykograficzne (Reychman 1980, 1985; Pátrovics, 2011; Varsányi 1974, 1988a, 1988b), a także czasopisma językoznawcze. Na szczególną uwagę zasługują „Polono-Hungarica” wydawane na Uniwersytecie Loránda Eötvösa oraz dwa periodyki slawistyczne, tj. budapeszteńskie „Studia Slavica-Hungarica” oraz debreczyńskie „Slavica”.

*aseretny@poczta.onet.pl; Centrum Języka i Kultury Polskiej w Świecie, Wydział Polonistyki, Uniwersytet Jagielloński, ul. Grodzka 64, 31-044 Kraków.

reinhold5@interia.pl; Centrum Języka i Kultury Polskiej w Świecie, Wydział Polonistyki, Uniwersytet Jagielloński, ul. Grodzka 64, 31-044 Kraków. 
Należy podkreślić, że w dwu ośrodkach uniwersyteckich Węgier, tj. na Uniwersytecie Loránda Eötvösa w Budapeszcie oraz na Katolickim Uniwersytecie Pétera Pázmánya w miejscowości Piliscsaba istnieją katedry filologii polskiej, skupiające badaczy języka polskiego, polskiej literatury oraz kultury. Do niedawna prężnym ośrodkiem polonistycznym był również Uniwersytet Debreczyński. Obecnie - podobnie jak na Uniwersytecie w Pécsu - jest prowadzony tam jedynie lektorat języka polskiego.

Polszczyzna jest więc obecna zarówno w językoznawstwie hungarystycznym, jak i glottodydaktyce węgierskiej. Jej badanie, opisywanie oraz nauczanie wymaga odpowiednich narzędzi. Jednym z nich są terminy. Ich wprowadzenie jest bowiem zawsze poprzedzone analizą, wyjaśnieniem, a następnie zdefiniowaniem pojęć, do których mają się odnosić.

\section{TERMIN}

Termin jest szczególnym przypadkiem nazwy. Jest to wyraz lub połączenie wyrazowe o ustalonym znaczeniu, które zostało arbitralnie przyporządkowane do pojęcia należącego do określonej dziedziny wiedzy (por. Babik 2010, s. 57). Terminy są najbardziej informacyjnie nośnym składnikiem języka nauki lub profesjolektu ${ }^{1}$. Dzięki nim możliwe jest zarówno porządkowanie wiedzy i jej transfer, jak i generowanie oraz upowszechnianie informacji naukowej. Wszystkie te działania podnoszą zaś poziom ludzkiej świadomości, pobudzają ciekawość poznawczą, przyczyniając się do postępu.

Terminy charakteryzuje jednoznaczność. W przeciwieństwie do innych wyrazów języka naturalnego nie zmieniaja one znaczeń w zależności od kontekstu, w jakim się pojawiają. Nie konotują też żadnych treści i są znaczeniowo neutralne (nie zawierają elementów uczuciowo-ekspresywnych) (Lukszyn, Zmarzer 2001, s. 21).

Problematyką tworzenia nowych terminów zajmował się w latach 60. Mazur (1961). Analizując zagadnienie, sformułował zasady, którymi, jego zdaniem, należy się kierować, tworząc nowe nazwy. Są to następujące zasady:

- międzynarodowości - nazwa powinna być zgodna z tą, która ma już zasięg międzynarodowy,

- powszechności - nie należy zmieniać tych nazw, które się już rozpowszechnily,

${ }^{1}$ Zasadami porządkowania pojęć w poszczególnych dziedzinach wiedzy i działalności ludzkiej, ich definiowania oraz dobierania do nich terminów zajmuje się terminologia. Prace prowadzone w jej ramach wiążą się z normalizacją słownictwa, czyli dążeniem do tego, by, jeśli więcej niż jeden termin odnosi się do danego pojęcia, jednemu z nich nadać status oficjalny (zob. Grucza 2013, s.11). 
- rodzimości - nazwa powinna być oparta na słowach rodzimych,

- jednorodności - nazwa powinna być utworzona albo w całości z wyrazów rodzimych, albo w całości z obcych,

- logiczności - nazwa powinna nasuwać swoim brzmieniem możliwie najwięcej istotnych skojarzeń z odnoszącą się do niej definicją,

- systematyczności - nazwom kilku pojęć równorzędnych powinna odpowiadać nazwa pojęcia bezpośrednio nadrzędnego,

- zwięzłości - nazwa powinna zawierać tylko po jednej informacji na każdą okoliczność,

- jednoznaczności - nazwa powinna oznaczać tylko jedno pojęcie,

- jednomianowości - tylko jedna nazwa powinna oznaczać dane pojęcie,

- reproduktywności - nazwa powinna być oparta na wyrazie umożliwiającym tworzenie nazw pochodnych,

- jednolitości - nazwa powinna zawierać słowo wspólne grupie nazw pojęć pokrewnych,

- operatywności - nazwa powinna być krótka i łatwa do wymawiania oraz nie powinna nastręczać trudności w wymowie w zestawieniu $\mathrm{z}$ innymi wyrazami,

- poprawności - nazwa powinna być zgodna z wymaganiami poprawności językowej,

- emocjonalności - nazwa nie powinna wzbudzać sprzeciwów natury emocjonalnej, czyli inaczej mówiąc, powinna się podobać.

Analizując w niniejszym tekście nazwy ukute w języku węgierskim na potrzeby opisu polszczyzny, będziemy się odwoływać do powyższych zasad. Zostały one co prawda opracowane z myślą o terminach technicznych, jednakże naszym zdaniem, ze względu na wysoki poziom ogólności sformułowań zastosowanych w opisach, można je z powodzeniem przenieść na grunt językoznawstwa oraz glottodydaktyki².

\section{POLSKA TERMINOLOGIA JĘZYKOZNAWCZA NA WĘGRZECH}

Rozważając kwestie polskiej terminologii językoznawczej na Węgrzech, należy uwzględnić z jednej strony aspekt genetyczny i typologiczny obu języków, $\mathrm{z}$ drugiej natomiast ich mocne zakorzenienie w tradycji antycznej. Polszczyzna jest językiem indoeuropejskim, słowiańskim, fleksyjnym, natomiast węgierszczyzna jest językiem uralskim, ugrofińskim, aglutynacyjnym. Odrębności te sprawiają, że część kategorii gramatycznych - zarówno nominalnych, jak i werbalnych

\footnotetext{
${ }^{2}$ Podobną operację zastosowaliśmy w tekście analizującym polskie terminy ukute na potrzeby opisu węgierszczyzny (zob. A. Seretny, W. T. Stefańczyk, w druku).
} 
- w znacznym zakresie się nie pokrywa ${ }^{3}$. Zrodziło to potrzebę utworzenia nieobecnych w węgierszczyźnie terminów gramatycznych charakterystycznych dla polszczyzny i innych języków fleksyjnych ${ }^{4}$.

Terminologia, która jest przedmiotem analizy dalszej części artykułu, została zaczerpnięta $\mathrm{z}$ prac wspomnianych wcześniej autorów. W jej ocenie kierowaliśmy się z jednej strony doświadczeniem językoznawczym, z drugiej - glottodydaktycznym, ukutymi terminami posługują się bowiem dwie grupy odbiorców: węgierscy poloniści oraz nauczyciele zapoznający Węgrów z polszczyzną. Pierwszym pozwala opisywać strukturę języka należącego do innej rodziny, precyzyjnie nazywać w nim kategorie i zjawiska nieobecne w węgierszczyźnie; drugim pomaga w usprawnieniu procesu kształcenia językowego: przy poznawaniu kodu docelowego, wyjściowy zawsze stanowi dla uczących się naturalny system odniesień ${ }^{5}$.

\subsection{KATEGORIE IMIENNE}

W zakresie kategorii imiennych omawiane różnice obejmują rodzaj oraz przypadek. Węgierszczyzna jest językiem bezrodzajowym, język polski natomiast jest językiem mającym kategorię rodzaju gramatycznego. Ma też zdecydowanie bardziej niż polszczyzna rozbudowany system przypadków.

$\mathrm{Na}$ określenie rodzaju gramatycznego stosuje się termin nem lub ściślej nyelvtani (grammatikai) nem $\mathrm{w}$ odróżnieniu od rodzaju naturalnego, $\mathrm{t}$. természetes (biológiai) nem. Ten ostatni występuje w języku węgierskim i jest realizowany na dwa sposoby: leksykalnie lub słowotwórczo, np.:
férfi 'mężczyzna' - asszony 'kobieta'
$\rightarrow$ rodzaj realizowany leksykalnie
férj 'mąż' - feleség 'żona'
tanár 'nauczyciel' - tanárnö 'nauczycielka' $\rightarrow$ rodzaj realizowany słowotwórczo titkár 'sekretarz' - titkárnö 'sekretarka'.

Niekiedy, co ciekawe, rodzaj naturalny jest wyrażany bardziej precyzyjnie w bezrodzajowym języku węgierskim niż w posiadającej rodzaj polszczyźnie, np. leksem królowa ma dwa odpowiedniki węgierskie, tj.:

\footnotetext{
${ }^{3}$ Oba języki cechuje też wiele podobieństw, które występują na wszystkich płaszczyznach systemu językowego (zob. A. Seretny, W. T. Stefańczyk, w druku).

${ }^{4}$ Różnice wynikające z genetycznej, a także typologicznej odrębności (obcości) węgierszczyzny, sprawiły, że polscy hungaryści stanęli przed podobną koniecznością - musieli nazwać kategorie i zjawiska typowe dla węgierskiego, a nieobecne w polszczyźnie (zob. A. Seretny, W. T. Stefańczyk, w druku).

${ }^{5}$ Znajomość metajęzyka opisu gramatycznego jest konieczna w przypadku eksplicytnego nauczania systemu językowego, z którym najczęściej mamy do czynienia na filologiach obcych (zob. Seretny 2015).
} 
királyné 'królowa, żona króla' (derywat z odmężowskim sufiksem -né);

királynő ‘królowa, kobieta król' (złożenie z członami király ‘król’ i nö 'kobieta').

Terminy nyelvtani nem/grammatikai nem oraz természetes nem/biológiai nem mają różną budowę. Nyelvtani nem i természetes nem to formacje rodzime, jednorodne, jednolite i logiczne w rozumieniu Mazura (1961), podczas gdy grammatikai nem oraz biológiai nem są zestawieniami hybrydowymi, przez co naruszają sformułowaną przez niego zasadę jednorodności. Dla użytkowników oba wyrażenia są równie przyjazne - grammatikai i biológiai ze względu na swoje greckie korzenie, nyelvtani i természetes z powodu przezroczystości semantycznej (jasnej motywacji). Dlatego też w opisach językoznawczych oraz podręcznikach do nauki polszczyzny traktowane są jako dublety.

W tradycyjnych polskich opracowaniach wyodrębnia się trzy rodzaje gramatyczne - męski (masculinum), żeński (femininum) i nijaki (neutrum) przejęte ze szkoły antycznej. W węgierskiej tradycji polonistycznej nazywa się je odpowiednio terminami hímnem' rodzaj męski', nönem 'rodzaj żeński”, semlegesnem 'rodzaj nijaki'. Zostały one, podobnie jak i poprzednie, tj. nyelvtani nem i természetes nem, stworzone w oparciu o zasadę rodzimości, jednorodności, jednolitości i logiczności. Naruszenie zasady międzynarodowości (w światowej literaturze językoznawczej rozpowszechnione są określenia proweniencji łacińskiej) kompensują reguły powszechności i logiczności oraz emocjonalności - terminów tych w języku węgierskim używa się bowiem również w odniesieniu do innych języków mających kategorię rodzaju gramatycznego (zasada powszechności); ze względu na jasną motywację są one także „zrozumiałe”: hím - to 'samiec', nö zaś to 'kobieta' (zasada logiczności).

Dość osobliwą cechą języka polskiego jest fakt, że w liczbie mnogiej występują dwie dodatkowe kategorie rodzajowe - rodzaj męskoosobowy i niemęskoosobowy. Jest to cecha typowo polska, nieistniejąca w innych językach słowiańskich. Na określenie tych kategorii nie zostały dotychczas ukute odpowiednie terminy $\mathrm{w}$ tradycji węgierskiej. Nazywa się je opisowo, tj. hímnemü személyt jelentő alak (dosłownie - postać rodzaju męskiego oznaczająca osoby) oraz hímnemü nem személyt jelentö alak, nőnem és semlegesnem (dosłownie - postać rodzaju męskiego nieoznaczająca osób, rodzaj żeński i nijaki). Trudna pojęciowo kategoria nie została więc nazwana za pomocą terminu. Węgierscy badacze polszczyzny wolą bowiem posługiwać się dość długą i skomplikowaną definicją opisową niż tworzyć wątpliwej jakości nazwę. Rozwiązanie to, neutralne na gruncie językoznawczym, jest także akceptowalne w dydaktyce języka - definicja dobrze bowiem oddaje naturę pojęcia, do którego się odnosi, co z punktu widzenia uczących się - jest najważniejsze.

W części nowszych ujęć językoznawczych (np. Grzegorczykowa, Laskowski, Wróbel (red.) 1998, Bańko 2002) na podstawie postaci biernika liczby pojedynczej wyodrębnia się dodatkowo rodzaj męskożywotny (męskozwierzęcy) oraz męskonieżywotny. W tradycji węgierskiej nie ukuto dotychczas odpowiednich 
terminów nazywających te pojęcia. Kategorie te określa się - podobnie jak w wielu polskich ujęciach (por. np. Klemensiewicz 1984, Włodarczyk 2009) - jako élö fönevek 'rzeczowniki żywotne' i élettelen fönevek 'rzeczowniki nieżywotne'. Jest to - jak się wydaje - rozwiązanie optymalne, stosuje się je bowiem w odniesieniu do wszystkich fleksyjnych języków słowiańskich, w których - mimo że istnieje kategoria żywotności - nie wyodrębnia się dodatkowych rodzajów męskich. Terminy są precyzyjne i zwięzłe. Sformułowane zostały zgodnie z zasadą rodzimości, jednolitości, jednorodności i logiczności (élő - 'żyjący'), co zadecydowało o ich upowszechnieniu i akceptacji (zasada emocjonalności).

Węgierszczyzna jest językiem o silnie rozbudowanym systemie przypadkowym. W zależności od ujęcia wyodrębnia się od 20 (Keszler 2000) do 25 przypadków (Csapláros 1963). Węgierski przypadek (węg. eset) jest zasadniczo jednofunkcyjny, natomiast przypadek polski kumuluje w sobie kilka funkcji. Jako przykład może posłużyć dopełniacz, który ma odpowiedniki w ośmiu różnych przypadkach węgierskich. Jego ekwiwalentami są następujące formy kazualne:

- possessivus, np.: Anna autója 'samochód Anny';

- allativus, np.: Annához 'do Anny';

- ablativus, np.: Annától 'od Anny';

- adessivus, np.: Annánál 'u Anny’;

- illativus, np.: Krakkóba 'do Krakowa';

- elativus, np.: Krakóból 'z Krakowa';

- terminativus, np.: augustusig 'do sierpnia';

- delativus, np.: autóról 'z samochodu' (z zewnątrz).

W węgierskiej tradycji językoznawczej w odniesieniu do przypadków węgierskich, na co wskazują również przytoczone przykłady, stosuje się terminologię łacińską, natomiast wielofunkcyjne przypadki polskie (także słowiańskie) nazywa się terminami węgierskimi. Przypadki polskie określane są w tradycji węgierskiej następującymi terminami:

- mianownik - alanyeset

- dopełniacz-birtokos eset

- celownik - részes eset

- biernik-tárgyeset

- narzędnik - eszközeset/leszközhatározó eset

- miejscownik - helyhatározó eset

- wołacz - megszólitó eset

Przyjęte rozwiązanie terminologiczne na poziomie makro ma charakter hybrydowy - część terminów pochodzi z łaciny, część jest rodzimej proweniencji. Na poziomie mikro wszystkie jednakże uformowane zostały zgodnie z zasadą jednolitości - nie ma więc takich, które są połączeniem terminu łacińskiego z nazwą rodzimą (jak miało to miejsce w przypadku rodzaju gramatycznego i na- 
turalnego). Zastanawiające jest jednakże to, dlaczego to, co rodzime, właściwe węgierszczyźnie nosi nazwy pochodzenia łacińskiego, to zaś, co obce - zostało oswojone, „zwęgierszczone”. Być może zadecydowały o tym względy glottodydaktyczne - nie wszyscy uczący się to obecni/przyszli filologowie, którzy z racji wykształcenia mają kontakt z terminologią łacińską.

Terminy rodzime nazywające polskie przypadki utworzone zostały zgodnie z zasadą rodzimości, jednorodności oraz jednolitości. Skoro zostały powszechnie przyjęte - nie budzą u odbiorców sprzeciwu emocjonalnego, czyli „podobają się”. Terminy mają przecież służyć użytkownikom i to oni zazwyczaj decydują ${ }^{6}$, które z nich się przyjmą, a które zostaną odrzucone.

Warto podkreślić, że polskim odpowiednikiem węgierskiego przypadka jest przyimek, na ogół pierwotny i końcówka fleksyjna, np. w formie Krakkóban morfem -ban jest ekwiwalentem polskiego przyimka $w$ oraz końcówki miejscownika $-e$. W niektórych polskich opracowaniach lingwistycznych przyimek traktowany bywa jako konstytutywny element przypadka (Kempf 1978; Kuryłowicz 1987). Należy w tym miejscu dodać, że węgierszczyzna jest językiem bezprzyimkowym. Na określenie prepozycji ukuto termin elöljárószó, który się stosuje nie tylko w odniesieniu do polszczyzny, lecz także do innych języków. Nazwa ta, utworzona zgodnie z zasadą rodzimości, jednorodności jest także powszechna, co świadczy o tym, że nie brzmi „dziwnie” i dobrze oddaje znaczenie pojęcia, do którego się odnosi.

Mówiąc o imiennych częściach mowy, warto dodać, że w języku węgierskim nie ma liczebników zbiorowych. Ich funkcje - podobnie jak w innych językach - pełnią liczebniki główne. Na określenie liczebników zbiorowych funkcjonuje w węgierszczyźnie termin gyüjtőszámnevek. I tu podobnie, jak w przypadku terminu elöljárószó także nazywającego kategorię nieobecną w języku węgierskim, termin ma brzmienie rodzime, przyjazne dla odbiorcy (zasada emocjonalności), sformułowany został zgodnie z zasadą logiczności (gyüjtö - 'zbierający'), tj. opiera się na jasnej motywacji.

\subsection{KATEGORIE WERBALNE}

Większość kategorii werbalnych, tj.:

- czas igeidö,

- tryb mód,

- liczba szám,

- strona alak,

- osoba személy

\footnotetext{
${ }^{6}$ Niekiedy nawet wbrew logice.
} 
jest wspólna w obu językach. Terminy je nazywające są zwięzłe, rodzime, logiczne i jednorodne. Są też w powszechnym użyciu, czyli zostały zaakceptowane tak przez środowisko badaczy języka, jak i glottodydaktyków.

$\mathrm{W}$ języku węgierskim nie ma kategorii aspektu, choć istnieje bogata literatura dotycząca postaci czasownika. W węgierszczyźnie funkcjonują dwa terminy określające aspekt czasownika - termin rodzimy igeszemlélet oraz internacjonalizm $^{7}$ igeaspektus (ige 'czasownik'). W tradycji węgierskiej czasownik niedokonany określany jest terminem folyomatos ige, natomiast czasownik dokonany jako befejezett ige, bądź imperfektív ige 'czasownik imperfektywny' perfektív ige 'czasownik perfektywny’. W przypadku nazw odnoszących się do zjawiska aspektu ponownie pojawiają się hybrydy. Określane mianem internacjonalizmów nazwy igeaspektus, perfektiv ige, imperfektív ige w istocie rzeczy są zestawieniami sprzecznymi z zasadą jednorodności - w ich strukturze pierwiastki obce sąsiadują bowiem z rodzimymi. Sama równoległość nazewnictwa, choć nie jest zjawiskiem pożądanym, bywa niekiedy trudna do uniknięcia zwłaszcza w opisach struktury języka. Pierwszym dobrze opracowanym systemem była bowiem łacina i to z niej wywodzi się wiele terminów będących w powszechnym użyciu w wielu językach, które funkcjonują samodzielnie lub obok rodzimych, lub paralelnie z nimi.

Co ciekawe, terminów rodzimych odnoszących się do aspektu używa się głównie w dydaktyce języka polskiego, natomiast w węgierskiej literaturze aspektologicznej dominują internacjonalizmy. Warto przytoczyć tu choćby niektóre z nich jak aspektológia 'aspektologia', aspektuspár 'para aspektowa' (też igeszemléleti párok 'pary aspektowe'), aspektuskategória 'kategoria aspektu', perfektiválás 'perfektywizacja', reimperfektiválás 'wtórna imperfektywizacja', aspektusoppozició 'opozycja aspektowa', álperfektiv ige 'czasownik pozornie dokonany', fázisaspektus 'aspekt fazowy', perfectiva tantum, imperfektiva tantum.

$\mathrm{W}$ polszczyźnie, podobnie jak w języku węgierskim, także funkcjonują dublety: czasownik 'dokonany'/'perfektywny', czasownik 'niedokonany'/'imperfektywny'. Mają one jednak podobny status: żaden nie jest ,przypisany” do określonej dziedziny nauki, choć wydaje się, że w polonistycznej praktyce glottodydaktycznej, zwłaszcza w nauczaniu początkujących, częściej sięga się do określeń o brzmieniu międzynarodowym niż do nazewnictwa rodzimego. A zatem odmiennie niż w dydaktyce węgierskiej.

Należy też podkreślić, że aspekt polski doczekał się kilku znakomitych opracowań węgierskich. Warto tu wymienić trzy istotne monografie: Aspektus a lengyel, a német és a magyar nyelvben. A lengyel aspektusjelentések német és magyar funkcionális megfelelöi [Aspekt w języku polskim, niemieckim i węgierskim. Funkcjonalne odpowiedniki niemieckie i węgierskie znaczenia polskiego aspek-

${ }^{7}$ Internacjonalizmy to wyrazy występujące w różnych językach. Ich zewnętrzna forma pisana lub mówiona pozwala na ich utożsamienie nawet osobie nie znającej danego języka. Są one swoistymi systemowymi ekwiwalentami przekładowymi. Powinny występować przynajmniej w trzech językach należących do różnych rodzin (Maćkiewicz 1984, s. 181). 
tu] (Pátrovics 2000), Az aspektus története és tipológiája [Historia i typologia aspektu] (Pátrovics 2004), A lengyel igeaspektus kérdései. Lengyel-magyar strukturális aspektusszótár [Zagadnienia polskiego aspektu. Polsko-węgierski strukturalny słownik aspektowy] (Pátrovics 2011).

\section{PODSUMOWANIE}

Ze względu na typologiczną i genetyczną odległość dzielącą polszczyznę od węgierszczyzny, w węgierskiej polonistycznej terminologii językoznawczej można wyróżnić trzy rodzaje terminów, które:

- mają odpowiednik semantyczny w języku polskim (np. pol. rodzaj - węg. nem);

- nie mają dokładnego odpowiednika, lecz można dla nich znaleźć odpowiednik funkcjonalny (np. pol. rodzaj nijaki - węg. semlegesnem);

- są traktowane jako nieprzekładalne (np. pol. rodzaj męskoosobowy - węg. brak: funkcjonuje definicja opisowa).

Do grupy pierwszej należą te terminy, które nazywają zjawiska i kategorie wspólne dla obu języków, w drugiej i w trzeciej - stanowiące o odmienności obu systemów ${ }^{8}$.

Wśród ukutych nazw zdecydowanie dominują formacje rodzime, utworzone jednakże bez naruszenia zasady emocjonalności ${ }^{9}$, czyli naturalnie brzmiące, a także logiczne, jednorodne i jednolite. Być może więc te cechy terminów użytkownicy uważają za najistotniejsze, pozostałe traktując jako mniej istotne.

Podsumowując rozważania, należy stwierdzić, że język polski jest stosunkowo dobrze opracowany na Węgrzech, o czym świadczą przytaczane w artykule monografie, podręczniki i prace leksykograficzne. Dzięki nim polonistyczna terminologia językoznawcza tworząca podstawy spójnego metajęzyka opisu gramatycznego jest ujednolicona, ma swą bogatą tradycję, jest konsekwentnie stosowana zarówno w literaturze przedmiotu, jak i w nauczaniu języka polskiego Węgrów.

${ }^{8}$ Do podobnych wniosków doszliśmy, analizując polską terminologię hungarystyczną (zob. Seretny, Stefańczyk, w druku).

${ }^{9}$ Formacje rodzime utworzone z naruszeniem zasady emocjonalności nie przyjmują się. Przykładem jest chociażby polski termin 'poimek', zastąpiony terminem 'postpozycja' (zob. Seretny, Stefańczyk, w druku). 


\section{BIBLIOGRAFIA}

Babik W., 2010, Słowa klucze, Kraków.

Bańczerowski J.,1976, Językoznawstwo kontrastywne a metodyka nauczana języków obcych (na materiale języka polskiego i węgierskiego), w: Neofilologia, Polskie Towarzystwo Neofilologiczne, Poznań, s. 84-100.

Bańczerowski J., 1995, Niektóre zagadnienia z zakresu nauczania języka polskiego Węgrów, „Przegląd Glottodydaktyczny", t. 14, Warszawa, s. 87-93.

Bańczerowski J., 2001a, Język polski na Wegrzech (badania naukowe, metodyka nauczania), w: Język polski w kraju i za granica, t. 2, Warszawa, 17-24.

Bańczerowski J., 2001b, Podstawy polsko-wegierskiej fonetyki i fonologii kontrastywnej, Budapest.

Bańczerowski J., 2007, Gramatyka komunikacyjna jako model kompetencji komunikacyjnej człowieka. Zarys problematyki, w: W. Figarski, J. Skrzypek (red.), Proces glottodydaktyczny w szkole, Warszawa, s. 15-25.

Bańczerowski J., Szabó D., Bakonyi I., 1980, Lengyel nyelvkönyv, Budapest.

Bańko M., 2002, Wyktady z polskiej fleksji, Warszawa.

Csapláros I., 1963, Zarys elementarnej gramatyki języka węgierskiego, Warszawa-Łódź.

Grzegorczykowa R., Laskowski R., Wróbel H. (red.), 1998, Gramatyka wspótczesnego języka polskiego, Warszawa.

Grucza S., 2013, Od lingwistyki tekstu do lingwistyki tekstu specjalistycznego, Warszawa.

Kempf Z., 1978, Próba teorii przypadków, cz. I, Opole.

Kerényi G., Szabó I., Varsányi I., 1966, Tanuljunk nyelveket - Lengyel nyelvkönyv, Budapest.

Keszler B. (red.), 2000, Magyar grammatika, Budapest.

Klemensiewicz Z., 1984, Podstawowe wiadomości z gramatyki języka polskiego, Warszawa.

Kuryłowicz J., 1987, Studia językoznawcze, Warszawa.

Lukszyn J., Zmarzer W., 2001, Teoretyczne podstawy terminologii, Warszawa.

Maćkiewicz J., 1984, Co to są tzw. internacjonalizmy? „Język Polski”, z. 3.

Mazur M., 1961, Terminologia techniczna, PWT, Warszawa.

Mroczko E., 1967, Zwięzła gramatyka języka węgierskiego, Warszawa.

Pátrovics P., 2000, Aspektus a lengyel, a német és a Magyar nyelvben. A lengyel aspektusjelentések német és magyar funkcionális megfelelöi, Budapest.

Pátrovics P., 2004, Az aspektus története és tipológiája, Budapest.

Pátrovics P., 2011, A lengyel igeaspektus kérdései. Lengyel-magyar strukturális aspektusszótár, Budapest.

Seretny A., 2015, Stownictwo w dydaktyce języka. Świat słów na przykładzie języka polskiego jako obcego, Księgarnia Akademicka, Kraków.

Seretny A., W. T. Stefańczyk, Węgierska terminologia językoznawcza w polskiej tradycji hungarystycznej (w druku).

Stefańczyk W. T., 1996, Fleksja polska. Lengyel alaktan, Debrecen.

Reychman J., 1980, Wielki słownik wegiersko-polski, Budapest.

Reychman J., 1985, Wielki słownik polsko-węgierski, Budapest.

Włodarczyk H., 2009, Lingwistyka na polonistyce krajowej i zagranicznej w dobie filozofii informatyczno-logicznej, „LingVaria” nr 1 (7), s. 65-79.

Varsányi I., 1974, Kis lengyel nyelvkönyv, Budapest.

Varsányi I., 1988a, Lengyel-magyar szótár, Budapest.

Varsányi I., 1988b, Magyar-lengyel szótár, Budapest. 
Anna Seretny, Wiesław Tomasz Stefańczyk

\section{POLISH TERMINOLOGY IN HUNGARIAN RESERCH AND LANGUAGE TEACHING}

Keywords: terminology, terms, Polish language, Hungarian language, language description, language learning/teaching

Summary. Since Polish and Hungarian belong to different language families, they are typologically and genetically different. Polish is a member of the Indo-European family. It is a Slavic and fusional language while Hungarian, a member of the Uralic language family, is Finno-Ugric, agglutinative one. Grammatical categories of both languages differ considerably, some phenomena which are specific to one of them, do not exist in the other. In Hungarian, for example, nouns do not have grammatical gender, there are no collective numerals, verbs do not have aspect, and nouns, though inflected, have different cases. Hungarian linguists thus so as to describe Polish language structure had to coin terms which would refer to grammatical categories/phenomena nonexistent in Hungarian. The article presents these terms, analyzing their nature and structure. 